\title{
Disposition Reference Identifier
}

National Cancer Institute

\section{Source}

National Cancer Institute. Disposition Reference Identifier. NCI Thesaurus. Code C87866.

A character or string used to name, or characterize a disposition reference. 